\title{
On the Effects of Computer-Assisted Teaching on Learning Results Based on Blended Learning Method
}

\author{
https://doi.org/10.3991/ijet.v14i01.9458 \\ Xinwen $\mathrm{Bi}^{(凶)}$, Xiaodan Shi \\ Beihua University, Jilin, China \\ bixinwen@yeah. net
}

\begin{abstract}
With the rapid development of the computer network technology, the blended learning method based on computer-assisted teaching has also been booming. This paper analyzes the connotations of blended learning and the architecture and main functions of the Moodle system by using research methods such as literature analysis, development and research method and sample survey method and then establishes a blended learning model based on the Moodle platform. Then, with the course of C Programming Language as an example, this paper gives detailed design of the process and implementation plan of the blended learning model based on the Moodle platform. At last, this paper investigates and analyzes the teaching effects among teachers and students participating in the learning activity, and the results show that the blended learning model based on the Moodle platform is helpful to improving the teaching effects and can serve as a reference for the innovation of teaching models and methods.
\end{abstract}

Keywords-Moodle platform; computer-assisted teaching; blended learning; teaching effect

\section{Introduction}

The development of computer technology and network technology has provided new ways for the innovation of modern educational teaching models and teaching methods. At present, the teaching models used by the educational community can be divided into three categories [1]. The first is the traditional classroom teaching, where the teacher plays the dominant role and the students lack initiative; the second is the Internet-based online teaching model, which has changed the relationship between teachers and students in the traditional teaching model and can satisfy the individual needs of learners. Researchers at home and abroad have conducted in-depth analysis of the characteristics of both traditional teaching and network-based teaching and found that the traditional teaching is irreplaceable and that either model cannot achieve great learning results if used alone. Therefore, a third teaching model has been proposed, i.e. the so-called blended learning model, which organically blends the previous two teaching models. 
Foreign scholars have studied the blended learning model since a long time ago. They proposed blended learning models such as the PCR project model, Purnima Valiathan model and Josh Bersin model [2], and applied them in postgraduate and doctoral courses and also corporate training, which achieved good results. As early as in 1991, Chinese scholars already developed the idea of blended learning. In recent years, theoretical and practical research on blended learning is gradually maturing. Chen and Liang et al. studied the practice of blended learning based on the Moodle platform [3]. The results show that the blended learning based on the Moodle platform helps improve the learning effects. However, through comparative analysis of related studies at home and abroad, it is found that the current blended learning model is not mature enough, and thus further research is needed.

Based on the above analysis, this paper attempts to use the theory and methodology of blended learning to build a blended learning model based on the Moodle platform according to the current situation of education and students and applies it to practical teaching. With the course $\mathrm{C}$ Language Programming as an example, this paper gives detailed teaching design and investigates and analyzes the effects of teaching, which proves that the teaching model, as a combination of the traditional classroom teaching and the pure online teaching, helps improve the teaching effects and can serve as a reference for the innovation of teaching models and methods.

\section{$2 \quad$ Related theories}

\subsection{Blended learning}

Connotations of blended learning: At present, scholars at home and abroad have different understandings about the connotation of blended learning. Through analysis and research of related literatures at home and abroad, it is concluded that blended learning is a learning method built on the constructivist learning theory, situational awareness and learning theory and education dissemination theory that combines the traditional teaching model with modern network technology and computer technology, fully utilizes their advantages and finally achieves the best portfolio of various teaching elements in the teaching process [4]. Blended learning is not only a mix of teaching resources, teaching media, learning environment, and learning theories, but also a combination of learning forms and methods, of well-structured and unstructured learning and of learning, practice, and performance support [5]. Therefore, blended learning can not only exert the guiding role of teachers, but also makes sure students play the main roles. Fig. 1 shows an octagonal chart of blended learning connotations [6]. 


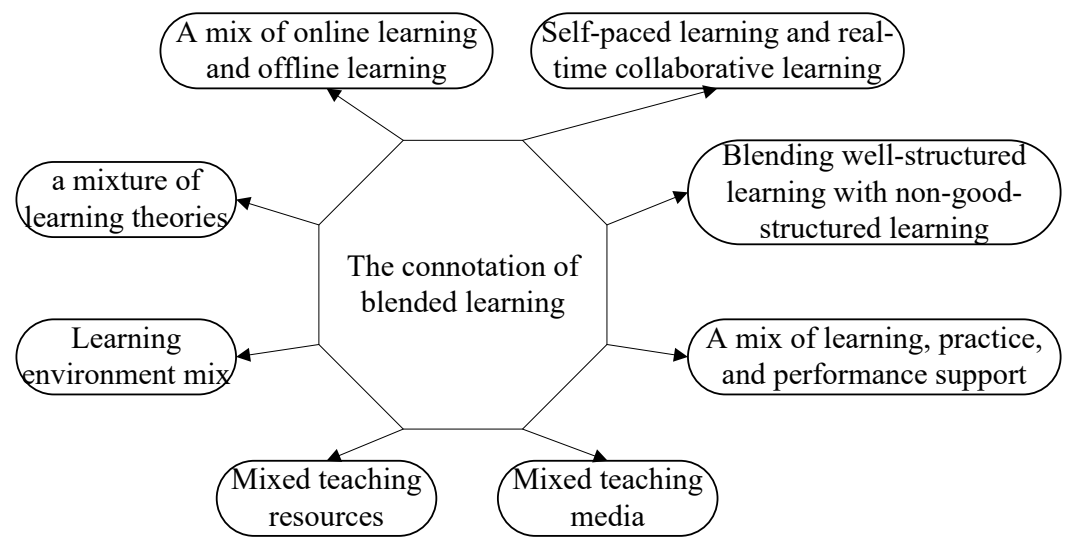

Fig. 1. An Octagonal Chart of Blended Learning Connotations

Process of blended learning: The traditional classroom teaching is a teachingcentred process - the entire teaching process is led by the teacher, and the teaching form is usually "speaking-listening-reading-memorizing-practicing" [7], which lacks variety and often separates theory from practice. The Internet-based online teaching is a "learning"-centred teaching process, which separates "teaching" from "learning" [8]. Students can learn by themselves at the time and place they select according to their needs, which turns passive learning into active learning. However, in the online teaching process, it is difficult for the teacher to control the learning progress of the students, and thus the teaching process is more fragmented, and there is no timely communication between the teacher and the students.

Blended learning integrates traditional classroom teaching with online teaching to give full play to their advantages. In this teaching process, the teacher can teach and organize students, while the students can also play their main roles in autonomous learning. The blended learning process includes course import, teaching design, teaching platform development and teaching implementation and evaluation [9]. Fig. 2 shows the process of blended learning.

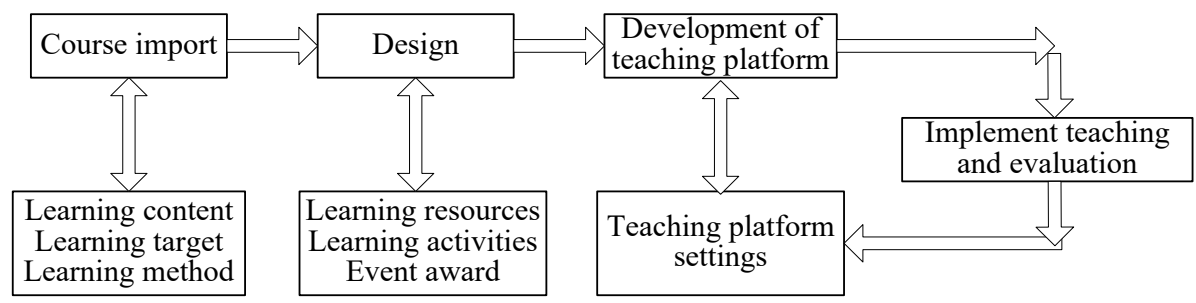

Fig. 2. Blended learning process 


\subsection{Moodle system architecture and main functions}

Moodle system architecture: The Moodle system [10] was developed and designed based on the constructivism theory. It has been widely applied as a powerful tool for teaching management around the world as it is easy to learn and user-friendly, and any user can download and use it for free. Fig. 3 shows the architecture of the Moodle system. This system uses PHP as the development language and the TCP/IP protocol to implement communication. As it uses the ADODB to wrap the operating details of the database, it can be used as a standalone application running on multiple platforms.

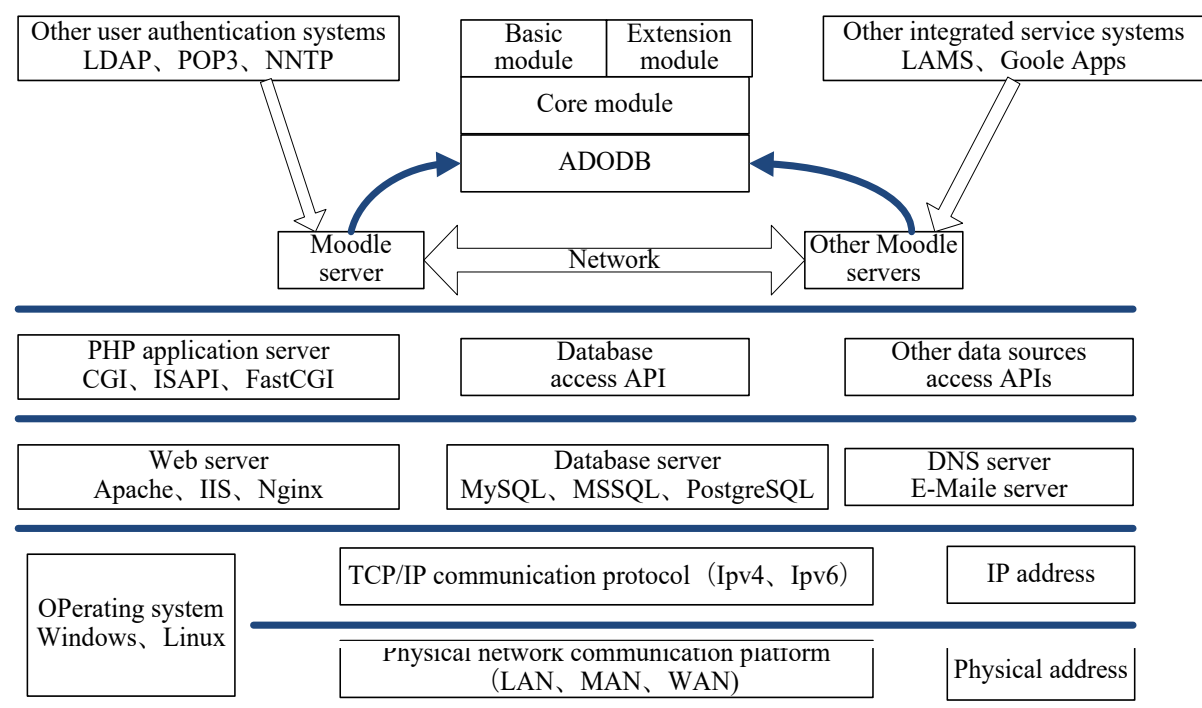

Fig. 3. Moodle's architecture

Main functions of the Moodle system: In the Moodle system, different permissions are assigned to different users according to their roles. This paper mainly introduces the main functions of the Moodle system from three roles - administrator, teacher and student [11].

Administrator: The administrator has the highest administrative and editing permission. The functions of the administrator can be mainly divided into three parts course administration, user administration and system administration. The specific functions are shown in Fig. 4. 


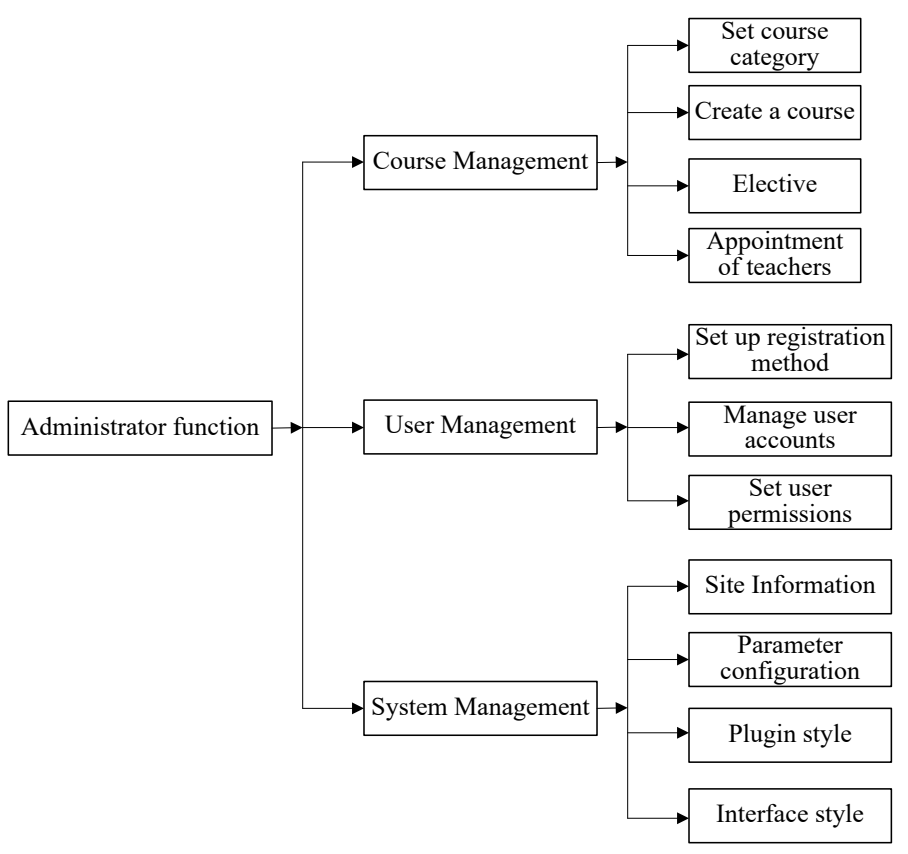

Fig. 4. Administrator functions

Teacher: The teacher's functions are authorized by the administrator, including teaching design, teaching preparation, teaching implementation, teaching evaluation and feedback [12]. Teachers can complete the design of teaching on the Moodle platform, including teaching plans, objectives, strategies and activities, and import relevant information of the course and teaching resources to prepare for teaching, and at the same time, they can also complete the teaching process, evaluate the students' learning status and give feedbacks on the platform. Fig. 5 shows the specific functions of teacher.

Student: The main functions of the students include viewing information related to the course, registering information, and signing up for courses via the Moodle platform. After successfully signing up for a course, students can view and learn related course resources through the platform, and complete the course learning in an inquirybased form or through group collaboration, etc. They can ask questions online, do exercises by themselves after class, attend online exams and also check their exam scores, teacher' evaluations on their learning status and after-class assignments. Fig. 6 shows the specific functions of the students [13]. 


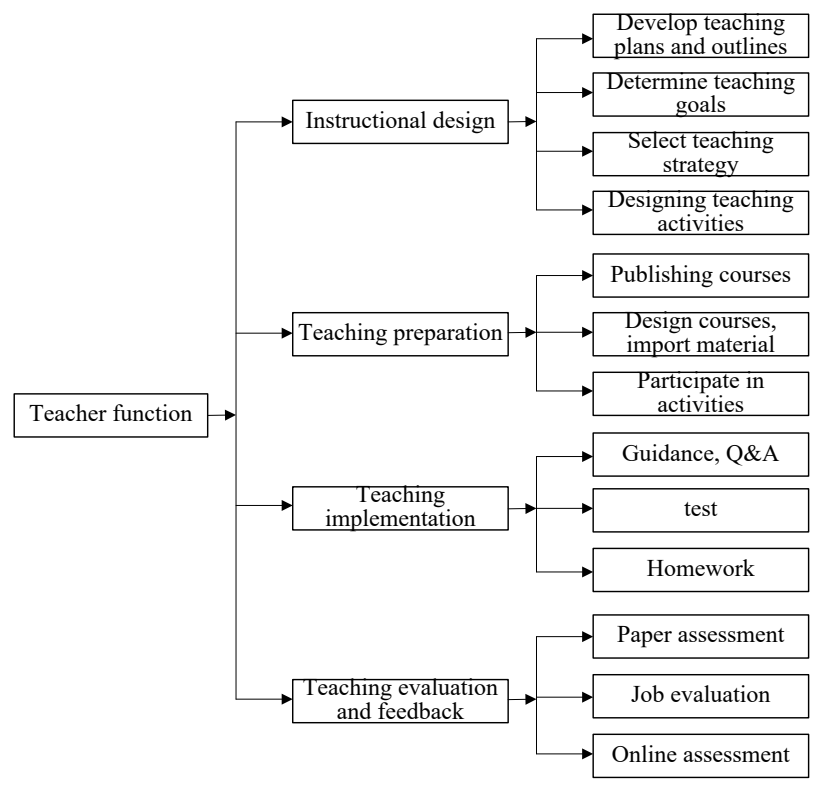

Fig. 5. Teacher functions

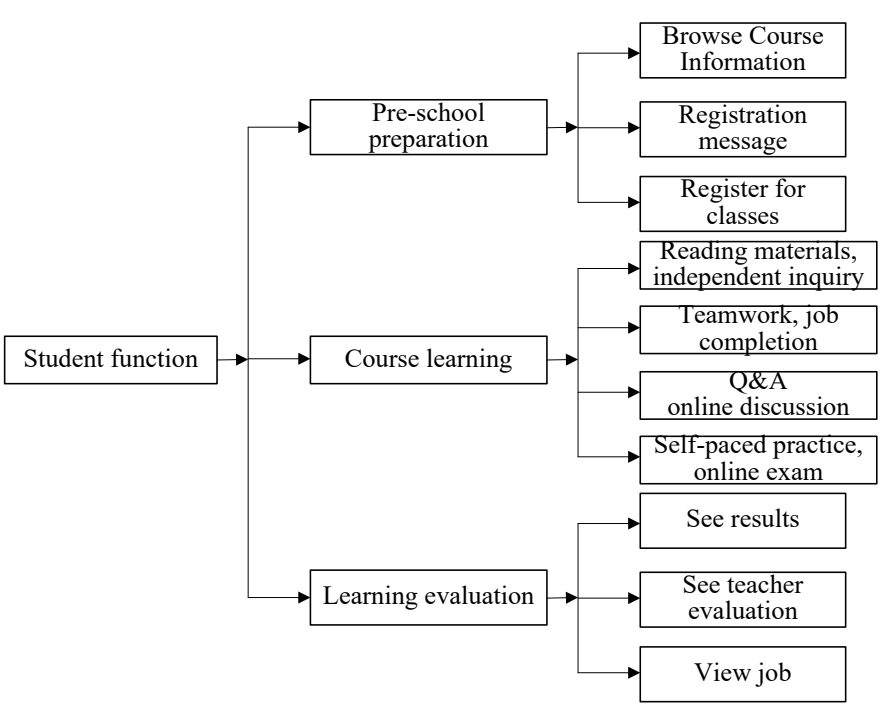

Fig. 6. Student functions 


\section{Construction of the blended learning model based on the Moodle platform and study of teaching effects}

\subsection{Construction of the blended learning model based on the Moodle platform}

In order to construct a kind of blended learning model with high generality, this paper takes the compulsory course $\mathrm{C}$ Language Programming opened in various universities in China as an example to design a blended learning process based on the Moodle platform.

Teaching design: The teaching process design is a prerequisite for the smooth development of the blended learning model. This paper uses the Moodle platform to design the following teaching activities [14]:

- Develop the corresponding teaching program and teaching objectives, and arrange the teaching process according to social needs, students' acceptance capabilities and the basic conditions of the university or college.

- Develop supporting teaching resources according to the teaching program in order to improve the quality of learning and facilitate teachers in giving consistent teaching.

- Establish a question bank that can meet the needs of students at different levels.

- Track students' online learning records and give timely tutoring.

- Build a learning platform based on Moodle. Students learn through this platform and their enthusiasm can be aroused by various evaluations, which will improve the quality of learning.

Fig. 7 shows the flow chart of teaching design [15].

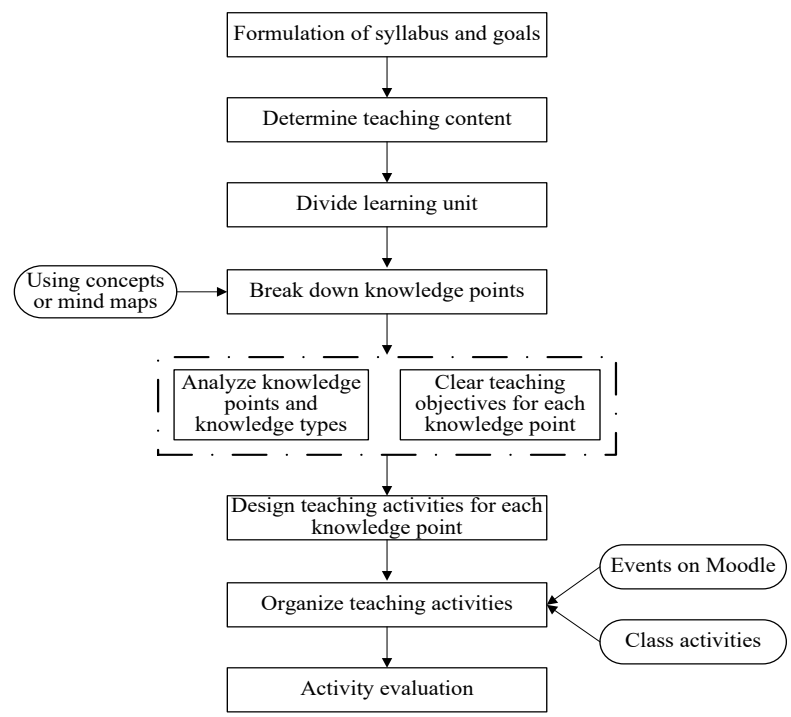

Fig. 7. Instructional design flow chart 
Blended learning model based on the Moodle platform: Fig. 8 shows the blended learning model based on the Moodle platform designed in this paper [16]. This model combines the traditional classroom teaching with the online teaching on the Moodle platform. The teacher introduces the teaching content and objectives to the students according to the established teaching plan and uses the Moodle platform for online teaching, and at the same time explains and answers students' questions face to face. Then the teacher uses the Moodle platform to give assignments. Students learn by themselves and discuss with others on the Moodle platform and complete the assignments under the guidance of the teacher. The teacher reviews the assignments completed by students through the Moodle platform, and adjusts the teaching content and method in time according to the classroom learning status and teaching evaluations after class.

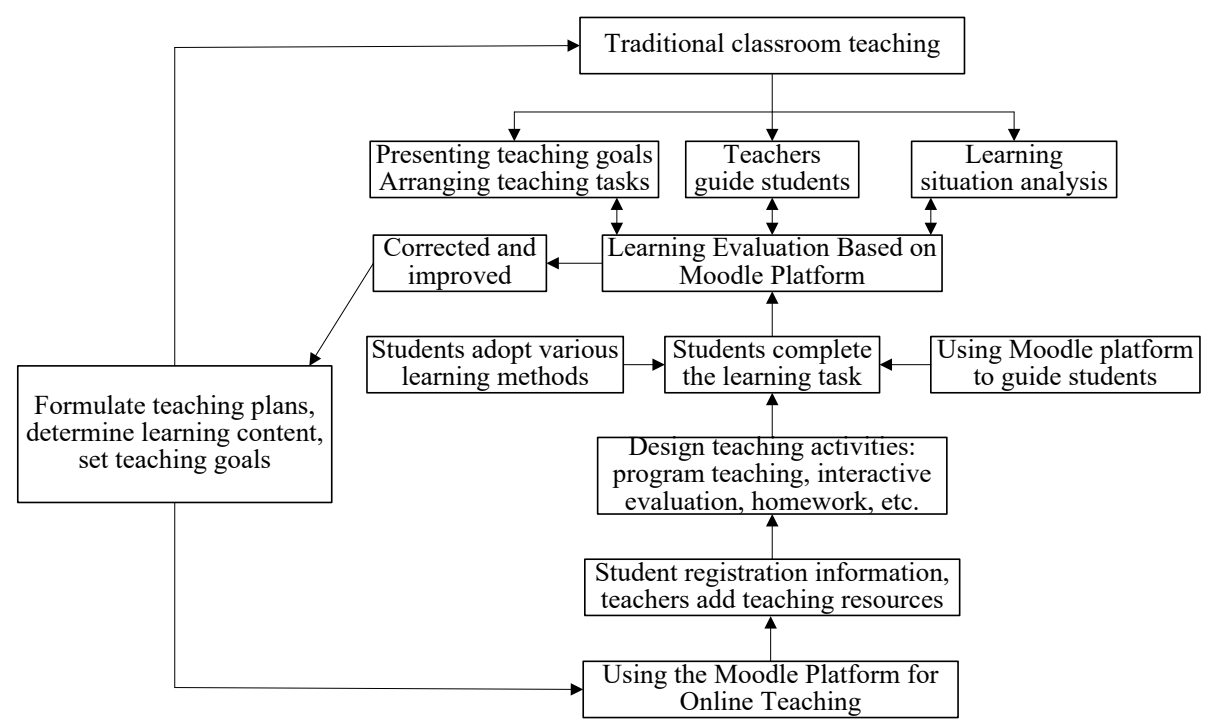

Fig. 8. Moodle-platform-based blended learning model

\subsection{Implementation plan}

Based on the teaching plan and the blended learning model designed above, with the course C Language Programming as an example, this paper develops a blended learning schedule to fully display the process of blended learning, as shown in Table 1. 
Table 1. Blended learning implementation plan for the course C Language Programming

\begin{tabular}{|l|l|l|l|l|}
\hline $\begin{array}{c}\text { Learning } \\
\text { activities }\end{array}$ & $\begin{array}{c}\text { Face-to-face } \\
\text { learning }\end{array}$ & \multicolumn{1}{|c|}{ Self-learning } & \multicolumn{1}{c|}{$\begin{array}{c}\text { Collaborative } \\
\text { learning }\end{array}$} & \multicolumn{1}{c|}{$\begin{array}{c}\text { Task-driven } \\
\text { learning }\end{array}$} \\
\hline Strategies & $\begin{array}{l}\text { Case and prob- } \\
\text { lem driven }\end{array}$ & $\begin{array}{l}\text { Internet-based Self- } \\
\text { learning }\end{array}$ & $\begin{array}{l}\text { Create a learning } \\
\text { group }\end{array}$ & $\begin{array}{l}\text { Set learning tasks } \\
\text { to drive learning }\end{array}$ \\
\hline Media & $\begin{array}{l}\text { Paper text- } \\
\text { books, multi- } \\
\text { media equip- } \\
\text { ment }\end{array}$ & $\begin{array}{l}\text { Paper Textbooks, } \\
\text { Electronic } \\
\text { Courseware, Video, } \\
\text { Test System in Moo- } \\
\text { dle }\end{array}$ & $\begin{array}{l}\text { Multimedia Devices, } \\
\text { BBS in Moodle, } \\
\text { wiki, Chat Room }\end{array}$ & $\begin{array}{l}\text { Multimedia } \\
\text { Devices, BBS in } \\
\text { Moodle, Chat } \\
\text { Room }\end{array}$ \\
\hline Evaluation & $\begin{array}{l}\text { Homework, } \\
\text { attendance, quiz }\end{array}$ & $\begin{array}{l}\text { Online learning } \\
\text { records, online testing }\end{array}$ & $\begin{array}{l}\text { Online job test and } \\
\text { group activity rec- } \\
\text { ords }\end{array}$ & $\begin{array}{l}\text { Homework, quiz, } \\
\text { experience report }\end{array}$ \\
\hline
\end{tabular}

\subsection{Evaluation of teaching effects}

In order to investigate the teaching effects of the blended learning model based on the Moodle platform in the actual teaching process, this paper conducts a sampling survey on the participating teachers and students.

Teacher evaluation: Evaluation of teachers helps teachers improves their teaching quality and enables them to adjust their teaching methods in a timely manner. Evaluation of teachers includes the evaluation on their guiding roles, information technology skills, classroom teaching design, online teaching and research capabilities and online teaching R\&D monitoring capabilities. Fig. 9 shows the survey statistics of the teacher evaluation on the Moodle platform, which indicates that the vast majority of teachers can meet the teaching requirements and have been recognized by the students.

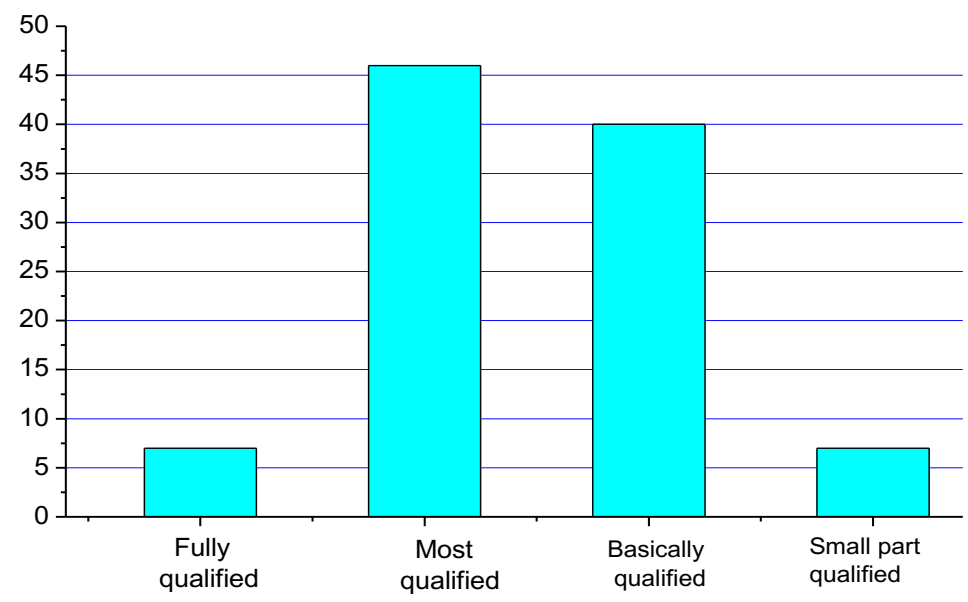

Fig. 9. The findings of the evaluation of teachers on Moodle

\section{Student evaluation}

Acceptance of the blended learning model based on the Moodle platform. From the survey results of the students' acceptance of the blended learning model based on the Moodle platform shown in Fig. 10, it can be seen that most students can accept this 
teaching model, indicating that this teaching method is fully functional and easy to operate. Only $5 \%$ of students indicated that they could not accept it probably because they were not skilled in computer operations or did not have easy access to the Internet.

Satisfaction with the blended learning model based on the Moodle platform. As shown in Fig. 11, 86\% of the students were very satisfied with this teaching model. Only $2 \%$ of the students expressed their dissatisfaction, indicating that the vast majority of the students recognized the blended learning model based on the Moodle platform and that the Moodle platform can provide great support for blended learning.

Mastery of the course: From the survey results in Fig. 12, it can be seen that $85 \%$ of students believed that this teaching model could promote students' mastery of the course, that $12 \%$ of students thought that the effect was average and that only $3 \%$ of students thought that there was no positive effect, indicating that most students had adapted to this teaching model and this model had some positive effect on their learning.

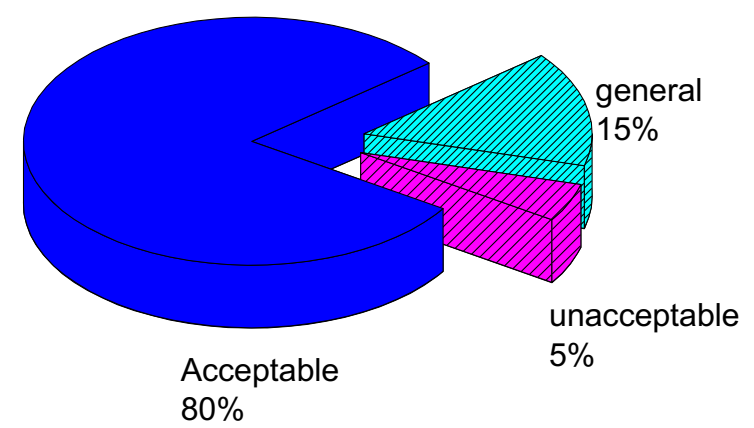

Fig. 10. Acceptance of Mixed Teaching Mode Based on Moodle Platform

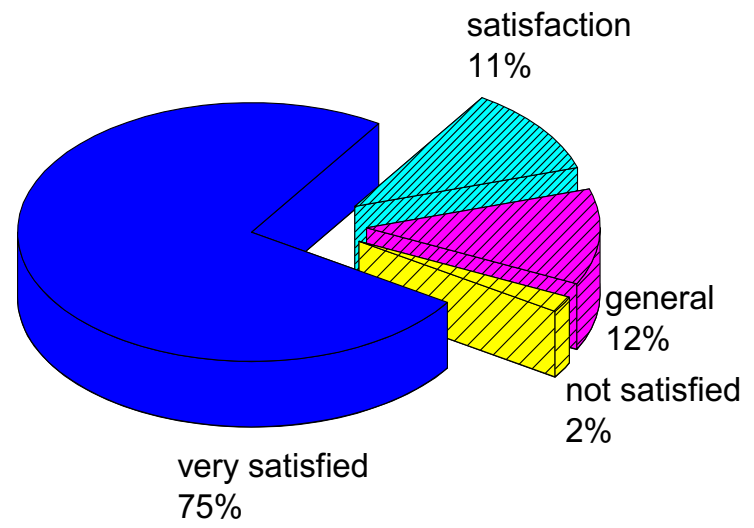

Fig. 11. Satisfaction with the blended teaching model based on the Moodle Platform 


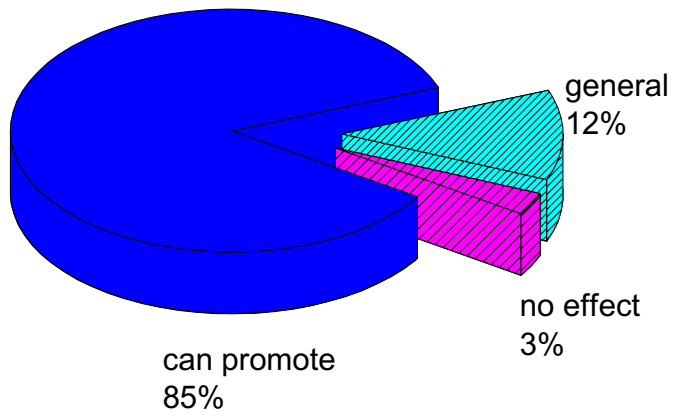

Fig. 12. Degree of mastery of the curriculum

\section{Conclusion}

This paper focuses on the blended learning model based on the Moodle platform and its teaching effects. By reviewing related literatures at home and abroad, and based on the analysis results of the sampling survey among teachers and students, this paper obtains the following conclusions:

- Based on the deep analysis of the blended learning model and the architecture and functions of the Moodle platform system, this paper establishes a blended learning model based on the Moodle platform.

- With the course of C Programming Language as an example, this paper gives detailed design of the process and implementation plan of the blended learning model based on the Moodle platform and implements this model.

- The sampling survey results show that this teaching model is recognized by both teachers and students and can effectively improve teaching effects.

\section{Acknowledgements}

This work has obtained the SPIHT-based color image lossless coding algorithm research (104918045), the reform practice of the hybrid teaching mode in the C language program under the background of new engineering, the micro-course design and teaching application research for user experience - the primary education major For example, funding.

\section{References}

[1] Gutiérrez, E., Trenas, M. A., Ramos, J., Corbera, F., Romero, S. (2010). A new moodle module supporting automatic verification of vhdl-based assignments. Computers \& Education, 54(2): 562-577. https://doi.org/10.1016/j.compedu.2009.09.006 
[2] Çırak Kurt, S., \& Yıldırım, İ. (2018). The students' perceptions on blended learning: A Q method analysis. Educational Sciences: Theory \& Practice, 18(2), 427-446. https://doi.org/10.12738/estp.2018.2.0002

[3] Martín-Blas, T., Serrano-Fernández, A. (2009). The role of new technologies in the learning process, Moodle as a teaching tool in physics. Computers \& Education, 52(1): 35-44. https://doi.org/10.1016/j.compedu.2008.06.005

[4] Romero, C., Espejo, P. G., Zafra, A., Romero, J. R., Ventura, S. (2013). Web usage mining for predicting final marks of students that use Moodle courses. Computer Applications in Engineering Education, 21(1): 135-146. https://doi.org/10.1002/cae.20456

[5] Zou, J., Liu, Q., Yang, Z. (2012). Development of a Moodle course for schoolchildren's table tennis learning based on competence motivation theory, its effectiveness in comparison to traditional training method. Computers \& Education, 59(2): 294-303. https://doi.org/10.1016/j.compedu.2012.01.008

[6] Seluakumaran, K., Jusof, F. F., Ismail, R., Husain, R. (2011). Integrating an open-source course management system (moodle) into the teaching of a first-year medical physiology course, a case study. Advances in Physiology Education, 35(4): 369-377. https://doi.org/10.1152/advan.00008.2011

[7] Hughes, G. (2007). Using blended learning to increase learner support and improve retention. Teaching in Higher Education, 12(3): 349-363. https://doi.org/10.1080/13562510701278690

[8] Porter, W. W., Graham, C. R., Spring, K. A., Welch, K. R. (2014). Blended learning in higher education, institutional adoption and implementation. Computers \& Education, 75(3): 185-195. https://doi.org/10.1016/j.compedu.2014.02.011

[9] López-Pérez, M. V., Pérez-López, M. C., Rodríguez-Ariza, L. (2011). Blended learning in higher education, students' perceptions and their relation to outcomes. Computers \& Education, 56(3): 818-826. https://doi.org/10.1016/j.compedu.2010.10.023

[10] Woltering, V., Herrler, A., Spitzer, K., Spreckelsen, C. (2009). Blended learning positively affects students' satisfaction and the role of the tutor in the problem-based learning process, results of a mixed-method evaluation. Advances in Health Sciences Education, 14(5): 725738. https://doi.org/10.1007/s10459-009-9154-6

[11] Alonso, F., López, G., Manrique, D., Viñes, J. M. (2005). An instructional model for webbased e-learning education with a blended learning process approach. British Journal of Educational Technology, 36(2): 217-235. https://doi.org/10.1111/j.14678535.2005.00454.x

[12] So, H. J., Brush, T. A. (2008). Student perceptions of collaborative learning, social presence and satisfaction in a blended learning environment, relationships and critical factors. Computers \& Education, 51(1): 318-336. https://doi.org/10.1016/j.compedu.2007.05.009

[13] Keeffe, M. (2010). Self-determined blended learning, a case study of blended learning design. Higher Education Research \& Development, 29(1): 1-13. https://doi.org/10.1080/07294360903277380

[14] Davis, H. C., Fill, K. (2007). Embedding blended learning in a university's teaching culture, experiences and reflections. British Journal of Educational Technology, 38(5): 817828. https://doi.org/10.1111/j.1467-8535.2007.00756.x

[15] Mcnulty, J. A., Sonntag, B., Sinacore, J. M. (2009). Evaluation of computer-aided instruction in a gross anatomy course, a six-year study. Anatomical Sciences Education, 2(1): 2. https://doi.org/10.1002/ase.66

[16] Mcnulty, J. A., Halama, J., Dauzvardis, M. F., Espiritu, B. (2000). Evaluation of webbased computer-aided instruction in a basic science course. Academic Medicine, 75(1): 5965. https://doi.org/10.1097/00001888-200001000-00016 


\section{$7 \quad$ Authors}

Xinwen Bi (1983-), female, Jilin City, master student, lecturer, work unit: School of Computer Science and Technology, Beihua University, engaged in professional: computer application teaching, research direction: computer application technology. Participated in the project: Jilin Province Philosophical and Social Science Planning Fund Office project, research on personal information security and protection strategy in the era of big data; Jilin Provincial Education Science Research Leading Group Office, research on the construction and effect evaluation of mobile situational learning model under the "Internet + " environment; Jilin Province Science and Technology Department (soft science) project, the status quo and improvement countermeasures of the transformation of scientific and technological achievements in provincial universities in Changjitu. Research on SPIHT-based color image lossless coding algorithm (104918045), reform practice of hybrid teaching mode in C language program under the background of new engineering, micro-course design and teaching application research for user experience-Taking primary education as an example. Published 5 related core papers.

Xiaodan Shi, graduated from Beihua University with a Bachelor of Science degree in 2008 and graduated from Northeast Normal University in 2013 with a Master of Science degree. From 2008 working at Beihua University, engaged in research in the field of computer science. Published related papers on information technology applications.

Article submitted 31 June 2018. Resubmitted 27 July 2018. Final acceptance 31 August 2018. Final version published as submitted by the authors. 